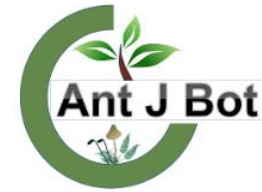

Received : 22.02.2018 Accepted : 27.04 .2018

\section{The comparative investigation of the antioxidant activities of some species belonging to the Lamiaceae and Poaceae families}

\author{
Ceren SAĞIR ${ }^{1}$, Zekiye Ayşe EVEREST ${ }^{1}$, Yüksel KELEŞ ${ }^{2 *}$ \\ ${ }^{1}$ Mersin University, Science and Art Faculty, Department of Biology, Mersin, Turkey \\ ${ }^{2}$ Mersin University, Education Faculty, Department of Science Education, Mersin, Turkey \\ *ykeles@mersin.edu.tr
}

\section{Lamiaceae ve Poaceae familyalarma ait bazı türlerin antiksidan savunma kapasitelerinin karşılaştırmalı olarak incelenmesi}

\begin{abstract}
The antioxidant compounds of plants have widely been investigated for the purpose of medical and industrial uses due to their aroma, color, smell and protective properties. In the study, 16 species from Lamiaceae and 14 species from Poaceae were collected from the Northeastern Mediterranean region and then they were analysed. The dry weight and water conditions of the plant samples were identified. It was identified that there wasn't a significant difference between these two families in respect to their values of chlorophyll and carotene. The mean xanthophyll content was higher in the Lamiaceae species $(236 \mu \mathrm{g}$ $\left.\mathrm{g}_{-}^{1} \mathrm{FW}\right)$ than in the Poacea species $\left(142 \mu \mathrm{g} \mathrm{g}^{-1} \mathrm{FW}\right)$ and total antioxidative capacity was higher in Lamiacea species $\left(5.19 \mathrm{mg}^{-1}\right.$ $\mathrm{FW}$ ) than Poaceae species $\left(3.49 \mathrm{mg} \mathrm{g}^{-1} \mathrm{FW}\right)$. On the other hand, mean soluble phenolics were measured as $1.83 \mathrm{mg} \mathrm{g}^{-1} \mathrm{FW}^{-1}$ Poaceae species and $1.67 \mathrm{mg} \mathrm{g}^{-1} \mathrm{FW}$ in Lamiaceae species. Superoxide dismutase enzyme activity was higher in Poaceae species. The findings revealed that significant differences could exist among the families and further comparative studies should be performed for the determination of the biochemical resources.
\end{abstract}

Key words: carotenoids; Mediterranean vegetation; phenolics; pigments; superoxide dismutase

Özet: Bitkilerin antioksidan bileşikleri aroma, renk, koku ve koruyucu özellikleri nedeniyle tıbbi ve endüstriyel kullanım amacıyla yoğun olarak araştırılmaktadır. Bu çalışmada, Lamiaceae'den 16 tür ve Poaceae'den 14 tür, Kuzeydoğu Akdeniz bölgesinden toplandı ve analiz edildi. Bitki örneklerinin kuru ağırlık ve su durumları belirlendi. Bu iki familyanın üyeleri arasında klorofil ve karoten değerleri bakımından önemli bir fark olmadığı belirlendi. Lamiaceae türlerinde ortalama ksantofil içeriği (236 $\left.\mu \mathrm{g} \mathrm{g}^{-1} \mathrm{FW}\right)$ Poacea türlerinden $\left(142 \mu \mathrm{g} \mathrm{g}^{-1} \mathrm{FW}\right)$ ve total antioksidatif kapasite Lamiacea türlerinde $\left(5.19 \mathrm{mg}^{-1}\right.$ FW) Poaceae türlerinden (3.49 $\left.\mathrm{mg} \mathrm{g}^{-1} \mathrm{FW}\right)$ daha yüksek bulundu. Buna karşın toplam çözünür fenolikler Poaceae türlerinde ortalama $1.83 \mathrm{mg} \mathrm{g}^{-1} \mathrm{FW}$, Lamiaceae türlerinde $1.67 \mathrm{mg} \mathrm{g}^{-1} \mathrm{FW}$ olarak ölçüldü. Süperoksit dismutaz enzim aktivitesi Poaceae türlerinde daha yüksek bulundu. Bulgular iki familya arasında önemli farklılıklar bulunabileceğini ve biyokimyasal kaynakların belirlenmesi bakımından karşılaştırmalı çalışmaların çoğaltılması gerektiğini ortaya koymaktadır.

Anahtar Kelimeler: Akdeniz vejetasyonu. fenolikler, karotenoidler, pigmentler, süperoksit dismutaz

\section{Introduction}

Biological systems have been protected from the destructive effects of oxygen by antioxidant defense mechanisms (Alscher and Hess, 1993). The mechanisms of tolerance or avoidance of oxidative stress differ among plant groups (Cai et al., 2004). The analysis of oxidative defense components can make a contribution for the determination of the differences among plant families. The primary elements serving for oxidative protection in plants are phenolic compounds of which antioxidants effects have been known and which have large diversity (Wojdylo et al., 2007; Rice-Evans et al., 1996). The strong water-soluble antioxidants such as glutathione and ascorbic acid are quite common in plant families. The levels of the oil-soluble antioxidants such as carotenoids and tocopherol differ among plant groups as well. The similar differences could be observed in antioxidant enzyme activities such as SOD, GR, catalase and peroxidases (Oncel et al., 2004).

Increasing reactive oxygen species in plants under stress are the harmful oxygen forms with higher chemical reactivity as compared with the oxygen molecules (Van Breusegem and Dat, 2006). Free radicals are highpowered, unstable compounds containing the electrons that not having constituted one or more pairs, in their outer atomic orbitals. Free radicals cause a damage by receiving electrons from many biological materials such as proteins, lipids, nucleic acids and coenzymes (Mitler, 2002).The studies evaluating the plant families with different biochemical characteristics in respect to their antioxidant capacities, reported significant differences (Cai et al., 2004; Wojdylo et al., 2007). There are evidences implying that the oxidative stress protection mechanisms of the Lamiaceae and Poaceae families, both of which have different biochemical characteristics, are also different (Öncel et al., 2004).

Lamiaceae's family has been represented with approximately 250 genus and 7000 species in the world (Kahraman et al., 2009). Members of this family range intensively in Mediterranean countries primarily, South West Asia and South America. Turkey is one of the important gene centers of Lamiaceae. This family has been represented with 574 species within 45 genus in Turkey (Güner et al., 2000). Most of the members of the Lamiaceae have a great importance in the fields of medical, pharmaceutical, food, cosmetic and perfumery because of being rich in essential oils, aromatic compounds, secondary metabolites (Başer, 1993). On the other hand, the use of ethnobotany is quite common among the members of the family (Matkowski et al., 2008; De Marino et al., 2012). Because of their high 
polyphenol content, Lamiaceae's plants were investigated as natural antioxidant resources (Rice-Evans et al., 1996).

The members of the Poaceae's family usually in the form of annual or perennial herbaceous plant, rarely in the form of bush or tree. Their roots are in the type of fibrous root and they contain some rhizome. Their stem is vertical, ascendant, leaning and creeping. Since their stem doesn't grow in width, the inner of their stem is empty, excluding nodiums. Their seeds are rich in starch. This cosmopolite family contains about 650 genus and species of much more than 9000. It has 512 species belonging to 142 genus in Turkey (Guner, 2000). It's many genus have economical value as being cultivated. In addition, it's species with sugar and oil contents are also available. They are feed and food plants which are rich in antioxidant phenolic acids and xylooligosaccharides (Reddy and Krishnan, 2013).

The species belonging to the Poaceae and Lamiaceae have been the subject of many studies in respect to their antioxidative capacities (Cai et al., 2004; Markowskaya et al., 2012). In this study, it was intended to perform comparative investigation of the antioxidative capacities of Poaceae and Lamiaceae families and determination of whether any difference exist in respect to their antioxidative capacities. The findings of this study can make a useful contribution for the determination of the systematical, physiological and biochemical characteristics of both families. Lamiaceae and Poaceae's species, which exist commonly in the Eastern Mediterranean region, were collected from different localities and analysed in laboratory in respect to their content of antioxidant featured substances and enzymes. It should not purely be a review of the subject area, and should not contain the findings or the conclusions.

\section{Material and Methods}

\subsection{Plants}

The plants which are the subject of the study were collected in July and August 2011 from the Çamliyayla (Gopter-Çuvalgi), Kazanlı, Apsun, Bükdeğirmeni, Kuyuluk, Aydıncık, Değirmençay, Işı1klı ve Gözne districts, which situated within the borders of Mersin province. This area is located in C4 square according to the grid system specified in Turkey's flora.16 of the species of 30 plant investigated belong to the Lamiacea, 14 of them belong to the Poaceae. Only fresh leaves of Lamiacea's samples, both leaves and stems of Poaceae's samples were cut out and stored in a freezer. The samples were taken from three different region for each species, the results of the analysis were given in average values of these samples.

\subsection{Dry Weight and Relative Water Content (RWC)}

Leaf dry matter content were determined as the difference between fresh weight and dry weight after drying at $110^{\circ} \mathrm{C}$ for 24 hours in an oven. Measurements of relative water content (RWC) were taken from segments of leaves. After floating on distilled water that allowed the leaf segments to rehydrate for $2 \mathrm{~h}$ at $20^{\circ} \mathrm{C}$, they were blotted dry and weight. The same segments were dried overnight at $110^{\circ} \mathrm{C}$ and weight again. RWC of leaves was calculated according to formula: RWC $=100 \times[(f w-d w) /$ turgid w$\mathrm{dw})]$.

\subsection{Chlorophyll Content}

Chlorophyll extraction from fresh leaf material was carried out with $80 \%$ acetone (buffered to $\mathrm{pH} 7.8$ with phosphate buffer). The chlorophyll a, chlorophyll b and total chlorophyll measurements were done with spectrophotometer. Chlorophyll contents were calculated according to Porra et al. (1989) and chlorophyll a/b ratios were determined.

\subsection{Carotenoid Content}

Fresh leaf material $(0.5 \mathrm{~g})$ were ground in pre-chilled mortar in $5 \mathrm{ml}$ aceton containing $200 \mathrm{mg} \mathrm{Na} 2 \mathrm{SO} 4$ and then fitered through glass fiber disks (Whatmann GF/A). The volume of the aceton extracts was reduced in rotary evaporator and then resuspended in $1 \mathrm{ml}$ chloroform. Fifty microliters of the extracts and standarts were applied to slica gel TLC plates (20x20, $0.25 \mathrm{~mm}$ thickness). The chromatograms were developed with hexane, dietil eter, aceton, 60:30:20, v:v:v) (Moore, 1974). Xantophyll and $\beta$ caroten spots were scraped from the TLC plates and centrifuged in $5 \mathrm{ml}$ aceton for $5 \mathrm{~min}$ at $5000 \mathrm{~g}$. The absorbance of supernatants was determined at a wavelength of $450 \mathrm{~nm}$ by a spectrofootometer, against $\beta$ caroten and lutein standarts.

\subsection{Total Antioxidant Capacity}

$0.5 \mathrm{~g}$ plant sample was crushed in porcelain mortar with 5 $\mathrm{ml}$ methanol $(96 \%)$ for determination of total antioxidative capacity. The extract was centrifuged for 5 minutes at $5000 \mathrm{~g}$ and supernatant was taken. A reactive containing $6 \mathrm{M}$ sulfuric acid, $28 \mathrm{mM}$ sodium phosphate and $4 \mathrm{mM}$ ammonium molybdate was prepared.150 $\mu \mathrm{l}$ supernatant was mixed with the reactive in a test tube so that last volume would be $3 \mathrm{ml}$. The tubes was maintained at $95{ }^{\circ} \mathrm{C}$ for $90 \mathrm{~min}$. and then cooled until room temperature and their absorbances were measured at 695 $\mathrm{mm}$. Total antioxidative capacity was calculated as the equivalent of ascorbic acid (Prieto et al., 1999).

\subsection{Soluble Phenolic Content}

The frozen leaf samples $(0.5 \mathrm{~g})$ were rapidly plunged in 20 $\mathrm{ml}$ of $80 \%$ aqueous ethanol and boiled for $5 \mathrm{~min}$. After filtration through Whatmann no. 1 filter paper, ethanol was eliminated from the filtrate by evaporation in vacuum. Total soluble phenolics in the remaining water phase were determined spectrophotometrically with the FolinCiocalteu reagent (prepared by 1:1 dilution with distilled water), against the chlorogenic acid standard (Ferraris et al., 1987).

\subsection{Superoxide Dismutase Activity}

Frozen leaf material $(0.5 \mathrm{~g})$ were homogenized in $6 \mathrm{~mL}$ $0.1 \mathrm{M}$ potassium phosphate extraction buffer $(\mathrm{pH} 7$, containing $100 \mathrm{mg}$ insoluble PVP and $0.1 \mathrm{mM}$ EDTA) with Ultra Turrax. The homogenate was centrifuged for 5 min at $6000 \mathrm{Xg}$ and $4^{\circ} \mathrm{C}$. The supernatant was filtered through a Whatman GF/A glass fiber disc with a vacuum filtration system and stored at $-70^{\circ} \mathrm{C}$ (Schöner and Krause, 1990).

SOD activity was determined according to Beyer and Fridovich (1987). The reaction mixture $(3 \mathrm{~mL})$ contained potassium phosphate buffer $(\mathrm{pH} 8,0.025 \%$ Triton X-100 and $0.1 \mathrm{mM}$ EDTA), enzyme extract, $12 \mathrm{mM} \mathrm{L}$ methionine, $75 \mu \mathrm{M}$ nitroblue tetrazolium chloride (NBT) 
and $2 \mu \mathrm{M}$ riboflavin. The reaction mixture was kept under flourescent light for ten minutes at $25^{\circ} \mathrm{C}$. One SOD unit was described as the amount of enzyme where the NBT reduction ratio was $50 \%$. NBT reduction ratios were measured with a spectrophotometer adjusted to $550 \mathrm{~nm}$.

\subsection{Statistical Processing}

All analyses and measurements were made repetitively at least 3 times. The importance levels of the differences between the species belonging to the Lamiaceae and Poaceae families were determined through t-test for each parameter. The averages, standard deviations and t-test results were stated in the tables.

\section{Results}

Average dry weight was determined as $29.5 \%$, average RWC determined as $81.3 \%$ at Lamiaceae. The dry weight percentage varies between $15.5 \%$ (Salvia verticillata) and 46.8\% (Phlomis leucophracta) at this family (Table 1). The RWC values vary between $55.5 \%$ (Phlomis leucophracta) and $96.3 \%$ (Salvia verticillata). Average dry weight was determined as $31.9 \%$, average relative water content was determined as $74.0 \%$ at Poaceae. The dry weight percentage varies between $15.4 \%$ (Cynodon sp.) and $61.3 \%$ (Aegilops speltoides) at Poaceae. The RWC values vary between $29.3 \%$ (Aegilops speltoides) and $97.6 \%$ (Echinochloa colonum) at this family. It was observed that the dry weight percentages and the RWC values varied in a wide range in both families. The difference between the families is not statistically significant.

The chlorophyll a, b and total amounts of chlorophyll were analysed at the species belonging to both families. The average amount of chlorophyll a was determined as $1159 \mu \mathrm{g} \mathrm{g}^{-1} \mathrm{FW}$, the average amount of chlorophyll b was determined as $544 \mu \mathrm{g} \mathrm{g}^{-1} \mathrm{FW}$ and total average amount of chlorophyll was determined as $1704 \mu \mathrm{g} \mathrm{g}^{-1} \mathrm{FW}$ at Lamiaceae. Highest amount of chlorophyll a was identified at Phlomis leucophracta species of Lamiaceae, highest amount of chlorophyll b was identified at Sideritis rubriflora species of the same family (Table 1). The average amount of chlorophyl a was determined as 1103 $\mu \mathrm{g} \mathrm{g}^{-1} \mathrm{FW}$, the average amount of chlorophyl b was determined as $483 \mu \mathrm{g} \mathrm{g}^{-1} \mathrm{FW}$ and total average amount of chlorophyl was determined as $1586 \mu \mathrm{g} \mathrm{g}^{-1} \mathrm{FW}$ at Poaceae. The greatest amount of chlorophyll a was identified at Polypogon mospeliensis species of Poaceae, the highest amount of chlorophyll $\mathrm{b}$ was identified at Phalaris aquatica species of the same family. The differences identified in respect to the chlorophyl contents and chlorophyll $\mathrm{a} / \mathrm{b}$ ratio of these two families aren't statistically significant (Table 1, Figure 1).

Having separated with thin layer chromatography, the carotenoids were analysed by using $\beta$-carotene and their total xanthophyl content was analysed by using spectrophotometer. The average $\beta$-carotene was identified as $103 \mu \mathrm{g}$ g- $1 \mathrm{FW}$ at Lamiaceae, $84 \mu \mathrm{g} \mathrm{g}^{-1} \mathrm{FW}$ at Poaceae. Any statistically significant difference in respect to $\beta$ carotene content wasn't determined between these two families. Total average values of the xanthophyl content was measured as $236 \mu \mathrm{g} \mathrm{g}^{-1} \mathrm{FW}$ at Lamiaceae, $142 \mu \mathrm{g} \mathrm{g}^{-1}$ FW at Poaceae. While total values of the xanthophyl content vary between $88-382 \mu \mathrm{g} \mathrm{g}^{-1} \mathrm{FW}$ at Lamiaceae, vary between $44-304 \mu \mathrm{g} \mathrm{g}^{-1} \mathrm{FW}$ at Poaceae. There is a statistically significant difference $(\mathrm{P} \leq 0.01)$ between the total values of the xanthophyl content of both families.

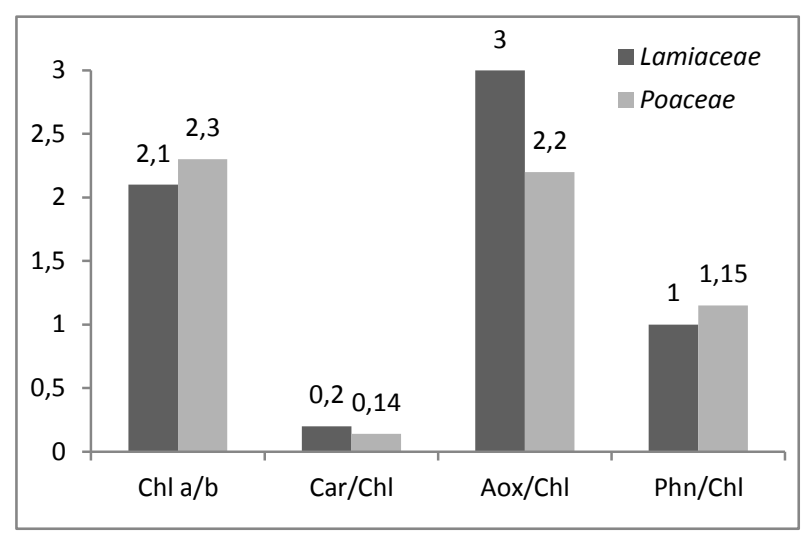

Fig. 1. Avarage values chlorophyll a/b, carotenoids/chlorophyll, total antioxidants/chlorophyll and soluble phenolics/chlorophyll in Lamiaceae and Poaceae families.

Total average antioxidative capacity was measured as 5.19 $\mathrm{mg} \mathrm{g}^{-1} \mathrm{FW}$ at Lamiaceae, 3,49 $\mathrm{mg} \mathrm{g}^{-1} \mathrm{FW}$ at Poaceae (Table 2). It was identified that Lamiaceae has higher antioxidant capacity than Poaceae has and this difference is statistically significant at $\mathrm{P} \leq 0.05$ level (Table 2 ). The species with the highest antioxidative capacity at Poaceae is Phleum pratense, the species with the highest antioxidant capacity at Lamiaceae is Sideritis perfoliata. Antioxidant/chlorophyll ratio higher at Lamiaceae (Figure 1). The highest antioxidant capacity on the dry weight basis was identified at Lamium garganicum species belonging to the Lamiacea (Figure 2).

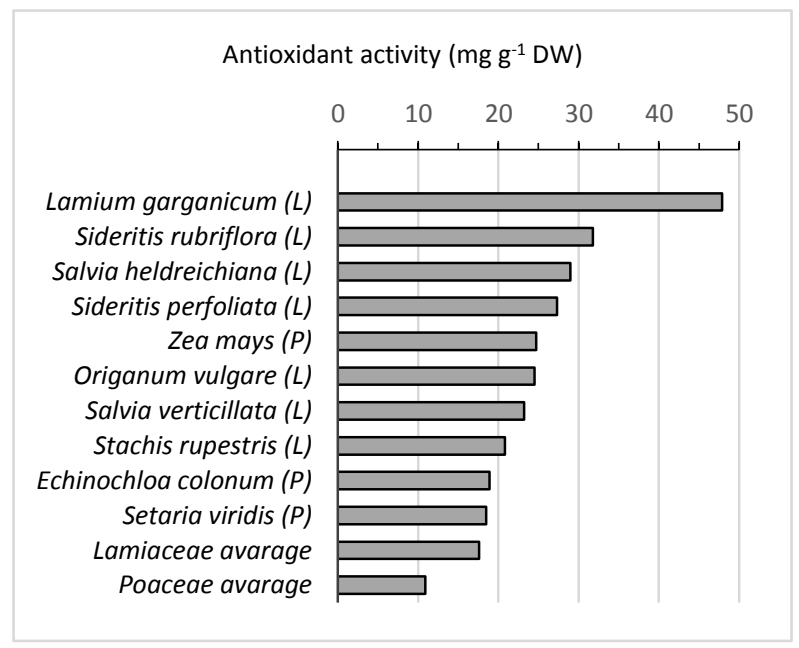

Fig. 2. Species with high antioxidant activity based on dry weight in Lamiaceae (L) and Poaceae $(\mathrm{P})$ families.

While the phenolic content was identified as $1,67 \mathrm{mg} \mathrm{g}^{-1}$ at Lamiaceae, it was identified as $1,83 \mathrm{mg} \mathrm{g}^{-1}$ at Poaceae. The sample of Lamiacea family with the highest phenolic content was identified as Sideritis rubriflora $\left(5,74 \mathrm{mg} \mathrm{g}^{-1}\right)$, the sample of Poaceae family with the highest phenolic content was identified as Zea mays $\left(3,82 \mathrm{mg} \mathrm{g}^{-1}\right)$ (Table $2)$. The amount of total phenolic substance is higher at Poaceae as compared with Lamiaceae, however, this difference is not statistically significant. The species with the highest soluble phenolic content on the dry weight basis were identified as Sideritis rubriflora and Zea mays (Figure 3). 


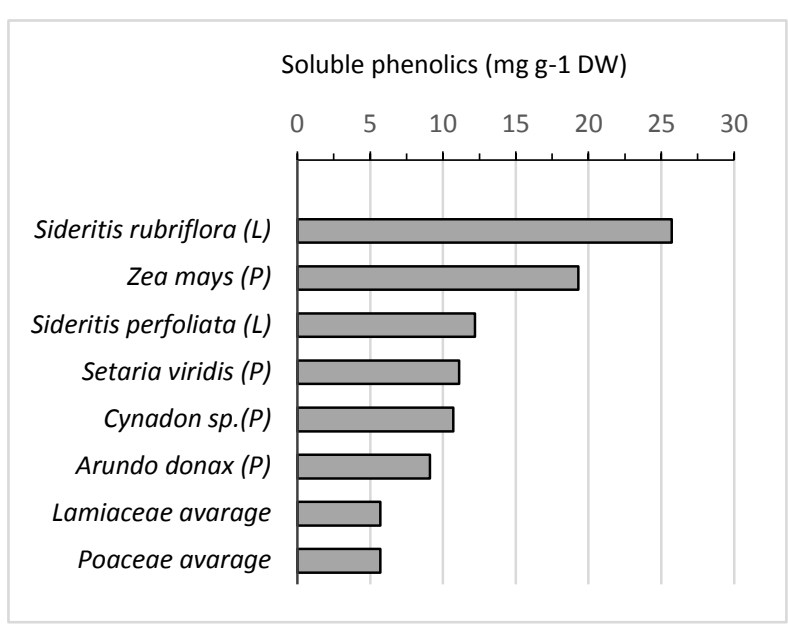

Fig. 3. Species with high soluble phenolics based on dry weight in Lamiaceae (L) and Poaceae (P) families,

The average amount of SOD was measured as 225 unit $\mathrm{g}^{-1}$ FW at Poaceae, as 213 unit $\mathrm{g}^{-1} \mathrm{FW}$ at Lamiacea. The highest amount of SOD was identified at the Phlaris pratense from Poaceae, at the species of Lamium amplexicaule from Lamiacea. Even though SOD content is higher at Poaceae than Lamiacea, but this difference is not statistically significant.

\section{Discussions}

The samples belonging to both families were collected in similar ecological conditions and in the same vegetative period. The average dry weight values of species of Lamiaceae and Poaceae families were identified as approximate to each other. However, significant differences were determined in respect to dry weight values among the members of the same family. These differences can be explained with soil, water conditions and microclimate differences (Oncel et al., 2004). That relative water content is higher at Lamiaceae's species can be associated with better water accession and better water conservation. It was reported in the study intending to determine the relationship between soil saltiness and RWC in the species of 6 turf (Poaceae) that the more soil saltiness increases, reduces RWC rates (Uddin et al., 2012).

Though the chlorophyl content significantly changes among the members of the same family, the difference between Lamiaceae and Poaceae is not significant. However, that the values of chlorophyl $b$ is higher at Lamiaceae leads to the ratio of $\mathrm{a} / \mathrm{b}$ to be increased in favor of Poaceae (Figure 1). Castrillo et al. (2001) investigated the contents of chlorophyl of 11 species belonging to Lamiaceae. They identified the ratios of $\mathrm{a} / \mathrm{b}$ above 2.0 at two species belonging to Nepetoidae subfamily, below 2.0 (1.41-1.76) at other species as well. The contents of chlorophyl of 11 species belonging to Poaceae were analyzed and it was identified that the ratios of chlorophyl $\mathrm{a} / \mathrm{b}$ varied between 3.5 and 2.0 (Uddin et al., 2012). The chlorophyl content and ratio of chlorophyl $a / b$ is associated with receive sunlight condition of plants. The lower ratio of chlorophyl $\mathrm{a} / \mathrm{b}$ is expected in plants growing in the shade.

According to the findings of this study, the amounts of both $\beta$-carotene and xanthophyl of Lamiaceae are higher than those of Poaceae (Table 2). The ratio of carotenoids per chlorophyl was found as 0.2 at Lamiaceae 0.14 at Poaceae (Figure 1). Carotenoids can be asserted to have a more important role in protection of photosynthetic system at the members of Lamiaceae. These findings are more different than those of Oncel et. al. (2004) who identified low-carotenoid contents at the species of Lamiaceae growing at stepe. Rather low amount of carotenoids $\left(0.34 \mu \mathrm{g} \mathrm{g}^{-1} \mathrm{DW} \quad \beta\right.$-carotene and $1.3 \mu \mathrm{g} \mathrm{g}^{-1}$ DW xanthophyl ) was identified through HPLC analysis in the edible parts of the Thymus vulgaris plant from Lamiaceae. However, it was identified in the same study that the reference values of this species related carotenoids were $29 \mu \mathrm{g} \mathrm{g}^{-1} \beta$-carotene and $19 \mu \mathrm{g} \mathrm{g}^{-1}$ xanthophyl (ElQudah, 2014). In a comparative study, the contents of carotenoid were identified as $260-430 \mu \mathrm{g} \mathrm{g}^{-1} \mathrm{FW}$ at 10 species of Poaceae family growing at tundra (Markowskaya et al., 2012). These high values of carotenoid can be resulted in due to tundra conditions.

The antioxidative capacity of the species of Lamiaceae investigated in this study was identified higher than that of the species of Poaceae (Table 2). The antioxidant capacity per chlorophyl is significantly high at Lamiaceae (Figure 1). The total antioxidative capacity on the dry weight basis is significantly high at Lamium garganicum species (Figure 2). Matkowski et al. (2008) identified a high antioxidative activity at the leaves of three species of Salvia (S. mitiorrhiza, S. przewalskii and S. verticillata). The authors offered the species of Salvia as source of potential antioxidant. But it was determined in the current study that the species of Sideritis have greater antioxidative capacity than the species of Salvia have. It was reported that 4 species of Lamiaceae growing naturally in Turkey, have significantly high antioxidative capacity and this situation is associated especially with content of polyphenol (Erdemoglu et al. 2006). The high values were identified in the study in which, antioxidative activities of the species of plant being known as Salvia and used as a drink in Turkey such that gallic acid equivalent was $130 \mathrm{mg}$ g-1 at Salvia fruticosa; $154 \mathrm{mg} \mathrm{g}^{-1}$ at Sideritis congesta, $120 \mathrm{mg} \mathrm{g}^{-1}$ at Sideritis pisidica (Erdoğan et al., 2010).

While total soluble phenolic contents of the species of Lamiaceae family distribute in a wide range, the phenolic values of the species of Poaceae were identified as approximate to each other (Table 2). A small difference in favor of Poaceae was identified with regard to soluble phenolic compounds per chlorophyl (Figure 1). It was revealed in a study which subject was antioxidative and antimicrobial activities of the species of Echinochloa colona belonging to Poaceae that this species showed high level of antioxidant activity. Total phenolic content of this species was stated as $734 \mathrm{mg} \mathrm{ml}^{-1}$ (Ajaib et al., 2013). It was stated that the antioxidative activity of corn silk (Zea sp.) was resulted from high contents of phenol and flavonoid and its total phenolic content was identified as $2.78 \mathrm{mg} \mathrm{g}^{-1}$ (Ebrahimzadehet et al., 2008). The species of poaceae family with high total contents of soluble phenolic were identified as Zea mays and Arundo donax (respectively 3.82 and $3.01 \mathrm{mg} \mathrm{g}^{-1} \mathrm{FW}$ ) in our study. The content of phenolic on the dry weight basis was identified significantly high at the species of Zea mays. These values are approximate to those identified by Ebrahimzadeh et al. 2008. 
It was reported in the studies investigating antioxidant activity of the species of Salvia growing in Turkey that the species with high total content of phenol have high antioxidant activity (Albayrak et al., 2008; Erdemoglu et al., 2006). Especially high values of the phenolic substances such as carsonic acid, rosmarinic acid, salvianolic acid are responsible for the antioxidative activity at the species of Salvia (Lu and Foo, 2002; Triantaphyllou et al., 2001).

Table 1. List of species from Lamiaceae and Poeceae, it's localities and their dry weight, RWC and chlorophyll values $(P$ values were not shown any significant difference).

\begin{tabular}{|c|c|c|c|c|c|}
\hline Lamiaceae species and locality & $\begin{array}{l}\text { Dry Weight } \\
(\%)\end{array}$ & $\begin{array}{l}\text { RWC } \\
(\%)\end{array}$ & $\begin{array}{l}\text { Chl-a } \\
\left(\mu \mathrm{g} \mathrm{g}^{-1} \mathrm{FW}\right)\end{array}$ & $\begin{array}{l}\text { Chl-b } \\
\left(\mu \mathrm{g} \mathrm{g}^{-1} \mathrm{FW}\right)\end{array}$ & $\begin{array}{l}\text { Total Chl. } \\
\left(\mu \mathrm{g} \mathrm{g}^{-1} \mathrm{FW}\right)\end{array}$ \\
\hline Calamintha nepeta (Apsun, Gözne) & $24.6 \pm 3.3$ & $74.3 \pm 6.1$ & $1000 \pm 35$ & $516 \pm 30$ & 1517 \\
\hline Lamium amplexicaule (Bükdeğirmeni) & $19.1 \pm 1.8$ & $95.7 \pm 3.9$ & $776 \pm 48$ & $379 \pm 22$ & 1155 \\
\hline Lamium garganicum (Değirmençay) & $16.7 \pm 3.0$ & $88.0 \pm 5.2$ & $1402 \pm 41$ & $646 \pm 27$ & 2048 \\
\hline Marrubium vulgare (Aydıncık, Bükdeğirmeni, Apsun) & $27.4 \pm 2.2$ & $64.8 \pm 2.9$ & $1290 \pm 57$ & $585 \pm 35$ & 1876 \\
\hline Micromeria myrtifolia (Kuyuluk, Değirmençay) & $33.9 \pm 0.7$ & $85.1 \pm 3.4$ & $990 \pm 18$ & $493 \pm 27$ & 1484 \\
\hline Origanum vulgare (Kuyuluk, Bükdeğirmeni) & $29.0 \pm 1.3$ & $85.4 \pm 3.2$ & $701 \pm 64$ & $365 \pm 38$ & 1080 \\
\hline Phlomis leucophracta (Bükdeğirmeni) & $46.8 \pm 2.5$ & $55.5 \pm 3.8$ & $2055 \pm 67$ & $866 \pm 41$ & 2921 \\
\hline Salvia frigida (Çamlıyayla- Çuvalgı) & $35.0 \pm 2.8$ & $89.4 \pm 4.1$ & $1285 \pm 30$ & $591 \pm 24$ & 1876 \\
\hline Salvia heldreichiana (Apsun) & $23.8 \pm 1.3$ & $89.3 \pm 1.7$ & $579 \pm 36$ & $307 \pm 22$ & 885 \\
\hline Salvia verticillata (Kuyuluk) & $15.5 \pm 1.4$ & $96.3 \pm 3.2$ & $941 \pm 27$ & $471 \pm 24$ & 1413 \\
\hline Salvia virgata (Apsun) & $17.8 \pm 1.0$ & $83.2 \pm 3.1$ & $882 \pm 31$ & $460 \pm 26$ & 1342 \\
\hline Sideritis perfoliata (Kuyuluk) & $43.3 \pm 0.5$ & $93.5 \pm 3.7$ & $1774 \pm 45$ & $560 \pm 31$ & 2335 \\
\hline Sideritis rubriflora (Iş1kl1) & $22.3 \pm 0.5$ & $84.8 \pm 3.5$ & $1952 \pm 34$ & $924 \pm 15$ & 2876 \\
\hline Stachys rupestris (Apsun) & $38.9 \pm 1.9$ & $62.9 \pm 4.4$ & $1243 \pm 31$ & $591 \pm 47$ & 1834 \\
\hline Teucrium chamaedrys (Çamliyayla- G.) & $32.0 \pm 0.9$ & $85.6 \pm 1.9$ & $906 \pm 27$ & $524 \pm 38$ & 1430 \\
\hline Teucrium polium (Aydıncık, Bükdeğirmeni, Çamlıyayla) & $45.8 \pm 3.4$ & $67.4 \pm 3.0$ & $762 \pm 54$ & $428 \pm 37$ & 1190 \\
\hline Lamiaceae Avarage & $29.5 \pm 10.1$ & $81.3 \pm 12.1$ & $1159 \pm 443$ & $544 \pm 160$ & $1704 \pm 583$ \\
\hline \multicolumn{6}{|l|}{ Poaceae species and locality } \\
\hline Aegilops speltoides (Çamliyayla) & $61.3 \pm 0.8$ & $29.3 \pm 0.9$ & $555 \pm 48$ & $319 \pm 27$ & 874 \\
\hline Arundo donax ( Kazanlı) & $32.9 \pm 1.3$ & $87.9 \pm 2.9$ & $584 \pm 115$ & $261 \pm 73$ & 845 \\
\hline Avena sterilis (Çamliyayla) & $42.8 \pm 3.0$ & $49.2 \pm 1.5$ & $617 \pm 122$ & $308 \pm 80$ & 925 \\
\hline Brachypodium pinnatum (Çamliyayla- G.) & $40.9 \pm 2.7$ & $78.2 \pm 2.5$ & $1316 \pm 44$ & $574 \pm 36$ & 1890 \\
\hline Brachypodium sylvaticum (Çamliyayla) & $39.9 \pm 1.9$ & $79.0 \pm 1.1$ & $606 \pm 80$ & $336 \pm 86$ & 942 \\
\hline Cynodon dactylon ( Kazanlı) & $19.3 \pm 2.6$ & $84.7 \pm 2.2$ & $1443 \pm 54$ & $637 \pm 41$ & 2080 \\
\hline Cynodon sp. ( Kazanlı) & $15.4 \pm 1.1$ & $94.2 \pm 0.7$ & $1006 \pm 45$ & $434 \pm 52$ & 1440 \\
\hline Echinochloa colonum (Kazanlı) & $19.0 \pm 0.6$ & $97.6 \pm 3.3$ & $1078 \pm 68$ & $489 \pm 43$ & 1567 \\
\hline Echinochloa crusgalli ( Kazanlı) & $19.0 \pm 0.9$ & $93.2 \pm 3.2$ & $1045 \pm 45$ & $437 \pm 37$ & 1482 \\
\hline Phalaris aquatica (Kazanlı) & $37.2 \pm 3.0$ & $56.3 \pm 2.0$ & $1456 \pm 56$ & $727 \pm 41$ & 2183 \\
\hline Phleum pratense (Çamlıyayla) & $54.6 \pm 4.2$ & $44.6 \pm 2.9$ & $1006 \pm 77$ & $481 \pm 45$ & 1487 \\
\hline Polypogon monspeliensis (Çamliyayla) & $27.2 \pm 2.5$ & $77.6 \pm 3.7$ & $1893 \pm 82$ & $713 \pm 76$ & 2606 \\
\hline Setaria viridis (Yenişehir) & $17.8 \pm 1.5$ & $80.6 \pm 5.5$ & $1670 \pm 57$ & $617 \pm 52$ & 2287 \\
\hline Zea mays ( Kazanlı) & $19.8 \pm 1.7$ & $93.2 \pm 3.2$ & $1169 \pm 48$ & $429 \pm 35$ & 1598 \\
\hline Poaceae Avarage & $31.9 \pm 14.2$ & $74.0 \pm 20.0$ & $1103 \pm 406$ & $483 \pm 146$ & $1586 \pm 546$ \\
\hline Statistics (T-test, $P$ values) & 0.60 & 0.24 & 0.73 & 0.30 & 0,58 \\
\hline
\end{tabular}


Table 2. Antioxidant compounds content and SOD activities of species from Lamiaceae and Poeceae families $(*$ significant at $P \leq 0.05$ and $* *$ significant $\mathrm{P} \leq 0.01$ ).

\begin{tabular}{|c|c|c|c|c|c|}
\hline Lamiaceae & $\begin{array}{l}\beta \text {-Caroten } \\
\left(\mu \mathrm{g} \mathrm{g}^{-1} \mathrm{FW}\right)\end{array}$ & $\begin{array}{l}\text { Xanthophyll } \\
\left(\mu \mathrm{g} \mathbf{g}^{-1} \text { FW) }\right.\end{array}$ & $\begin{array}{l}\text { Antioxidant } \\
\text { capacity } \\
\left(\mathrm{mg} \mathrm{g}^{-1} \text { FW) }\right.\end{array}$ & $\begin{array}{l}\begin{array}{l}\text { Soluble } \\
\text { phenolics } \\
\left(\mathrm{mg} \mathrm{g}^{-1} \text { FW) }\right.\end{array} \\
\end{array}$ & $\begin{array}{l}\text { Total SOD } \\
\text { (Unit } \mathbf{g}^{-1} \text { FW) }\end{array}$ \\
\hline Calamintha nepeta (Apsun, Gözne) & $82 \pm 6.4$ & $290 \pm 21.0$ & $4.1 \pm 0.43$ & $1,26 \pm 0,07$ & $197 \pm 32$ \\
\hline Lamium amplexicaule (Bükdeğirmeni) & $88 \pm 8.7$ & $186 \pm 12.3$ & $2.6 \pm 0.41$ & $1,07 \pm 0,08$ & $296 \pm 20$ \\
\hline Lamium garganicum (Değirmençay) & $164 \pm 14.4$ & $336 \pm 16.8$ & $8.0 \pm 0.22$ & $0,75 \pm 0,05$ & $186 \pm 26$ \\
\hline Marrubium vulgare (Aydıncık, Bükdeğirmeni, Apsun) & $114 \pm 15.2$ & $265 \pm 24.0$ & $4.1 \pm 0.71$ & $1,26 \pm 0,05$ & $193 \pm 45$ \\
\hline Micromeria myrtifolia (Kuyuluk, Değirmençay) & $160 \pm 15.0$ & $232 \pm 18.1$ & $2.8 \pm 0.19$ & $1,27 \pm 0,05$ & $193 \pm 23$ \\
\hline Origanum vulgare (Kuyuluk, Bükdeğirmeni) & $89 \pm 11.0$ & $124 \pm 19.2$ & $7.1 \pm 0.27$ & $0,98 \pm 0,05$ & $185 \pm 45$ \\
\hline Phlomis leucophracta (Bükdeğirmeni) & $116 \pm 22.1$ & $368 \pm 19.8$ & $3.0 \pm 0.25$ & $3,2 \pm 0,07$ & $175 \pm 14$ \\
\hline Salvia frigida (Çamlıyayla- Çuvalgı) & $124 \pm 11.4$ & $294 \pm 32.8$ & $3.6 \pm 0.91$ & $0,55 \pm 0,07$ & $181 \pm 16$ \\
\hline Salvia heldreichiana (Apsun) & $86 \pm 6.6$ & $165 \pm 13.5$ & $6.9 \pm 0.33$ & $1,45 \pm 0,01$ & $235 \pm 45$ \\
\hline Salvia verticillata (Kuyuluk) & $136 \pm 13.6$ & $382 \pm 22.5$ & $3.6 \pm 0.54$ & $0,39 \pm 0,08$ & $227 \pm 30$ \\
\hline Salvia virgata (Apsun) & $66 \pm 8.0$ & $187 \pm 23.9$ & $2.2 \pm 0.57$ & $0,14 \pm 0,09$ & $266 \pm 37$ \\
\hline Sideritis perfoliata (Kuyuluk) & $148 \pm 12.5$ & $340 \pm 26.0$ & $11.8 \pm 0.59$ & $5,3 \pm 0,07$ & $188 \pm 35$ \\
\hline Sideritis rubriflora (Iş1k11) & $92 \pm 8.4$ & $304 \pm 22.4$ & $7.1 \pm 0.25$ & $5,74 \pm 0,07$ & $221 \pm 40$ \\
\hline Stachys rupestris (Apsun) & $44 \pm 8.5$ & $92 \pm 15.2$ & $8.1 \pm 0.50$ & $0,9 \pm 0,08$ & $204 \pm 22$ \\
\hline Teucrium chamaedrys (Çamliyayla- G.) & $82 \pm 7.6$ & $157 \pm 13.5$ & $2.3 \pm 0.08$ & $0,23 \pm 0,1$ & $258 \pm 40$ \\
\hline Teucrium polium (Aydıncık, Bükdeğirmeni, Çamlıyayla) & $63 \pm 9.2$ & $88 \pm 7.5$ & $5.4 \pm 0.24$ & $2,17 \pm 0,08$ & $197 \pm 24$ \\
\hline Lamiaceae Avarage & $103 \pm 35$ & $236 \pm 95$ & $5.19 \pm 2.62$ & $1.67 \pm 1.63$ & $213 \pm 34$ \\
\hline \multicolumn{6}{|l|}{ Poaceae } \\
\hline Aegilops speltoides (Çamlıyayla) & $92 \pm 12.7$ & $127 \pm 7.1$ & $4.8 \pm 0.07$ & $1,7 \pm 0,05$ & $209 \pm 14$ \\
\hline Arundo donax ( Kazanl1) & $24 \pm 11.3$ & $72 \pm 6.9$ & $3.4 \pm 0.58$ & $3,01 \pm 0,14$ & $234 \pm 74$ \\
\hline Avena sterilis (Çamlıyayla) & $68 \pm 7.6$ & $84 \pm 8.0$ & $4.1 \pm 0.27$ & $1,94 \pm 0,08$ & $229 \pm 28$ \\
\hline Brachypodium pinnatum (Çamlıyayla- G.) & $84 \pm 15.9$ & $52 \pm 7.1$ & $1.7 \pm 0.30$ & $1,48 \pm 0,05$ & $188 \pm 62$ \\
\hline Brachypodium sylvaticum (Çamlıyayla) & $36 \pm 6.4$ & $115 \pm 9.5$ & $4.8 \pm 0.99$ & $1,58 \pm 0,25$ & $214 \pm 54$ \\
\hline Cynodon dactylon ( Kazanlı) & $128 \pm 18.6$ & $232 \pm 8.0$ & $2.9 \pm 0.57$ & $1,35 \pm 0,01$ & $223 \pm 39$ \\
\hline Cynodon sp. ( Kazanlı) & $88 \pm 8.1$ & $132 \pm 10.2$ & $2.2 \pm 0.40$ & $1,65 \pm 0,33$ & $161 \pm 24$ \\
\hline Echinochloa colonum (Kazanlı) & $132 \pm 16.7$ & $146 \pm 4.7$ & $3.6 \pm 0.44$ & $1,43 \pm 0,13$ & $210 \pm 22$ \\
\hline Echinochloa crusgalli ( Kazanlı) & $60 \pm 12.1$ & $97 \pm 5.2$ & $2.2 \pm 0.46$ & $1,43 \pm 0,06$ & $206 \pm 60$ \\
\hline Phalaris aquatica (Kazanlı) & $88 \pm 10.3$ & $304 \pm 26.8$ & $1.9 \pm 0.18$ & $1,71 \pm 0,07$ & $295 \pm 62$ \\
\hline Phleum pratense (Çamlıyayla) & $52 \pm 10.8$ & $148 \pm 10.4$ & $5.8 \pm 0.43$ & $1,33 \pm 0,08$ & $296 \pm 49$ \\
\hline Polypogon monspeliensis (Çamliyayla) & $104 \pm 7.9$ & $294 \pm 11.8$ & $3.4 \pm 0.44$ & $1,16 \pm 0,15$ & $196 \pm 34$ \\
\hline Setaria viridis (Yenişehir) & $180 \pm 7.9$ & $158 \pm 15.1$ & $3.3 \pm 0.43$ & $1,98 \pm 0,04$ & $241 \pm 28$ \\
\hline Zea mays ( Kazanlı) & $55 \pm 17.1$ & $44 \pm 7.7$ & $4.9 \pm 0.37$ & $3,82 \pm 0,14$ & $253 \pm 24$ \\
\hline Poaceae Avarage & $84 \pm 42$ & $142 \pm 84$ & $3.49 \pm 1.22$ & $1.83 \pm 0.70$ & $225 \pm 36$ \\
\hline Statistics (T-test, $P$ values) & 0.23 & $0.006^{* *}$ & 0.04* & 0.74 & 0.34 \\
\hline
\end{tabular}

The amounts of total phenolic were determined as Micromeria croatia $13,6 \%$, M. juliana $10,8 \%, M$. thymfolia $9,7 \%$ in the analyse performed with dried plant samples at the species of Lamiaceae growing in Croatia. It was stated that there was a strong positive correlation between phenolic compounds and antioxidative activity (Knezevic et al. 2011). High content of substance such as $13.4 \mathrm{mg} \mathrm{g}^{-1} \mathrm{FW}$ was identified at Lavandula angustifolia, in a study in which total content of phenolic of four species of Lamiaceae were investigated (Swedan, 2013). The reason why total content of phenolic of the species of Salvia have been identified as high in the literature is that extraction was performed with acid hydrolysis. Since acid hydrolysis wasn't used in our study, phenolic values with low solubility at the species of Salvia, high solubility at the species of Sideritis were identified. The highest values of soluble phenolic at dry weight basis were identified at Sideritis rubriflora (Figure 3). The average total amount of soluble phenolic is higher at Poacea than Lamiaceae. But the highest values of soluble phenolic were identified at two species of Sideritis. The high values of phenolic existing at some species of Lamiaceae may lead these species to be used as food, syrup and tea. The reasons why the species of Lamiaceae have been intensely investigated are phenolic compounds cause the inhibition of the production of fungal enzyme and of the enzymes produced by pathogens and removal of free radicals.

Unsuitable environmental conditions cause oxidative stress in plants. SOD enzyme has a critical role in 
protection of plants against oxidative stress (Keleş and Everest, 2008). Cross tolerance occurs in the plants being affected simultaneously from a great number of stress factors in natural conditions. One of the important components of cross tolerance is an increase in SOD activity (Bowler et al., 1992). In the study in which effects of both temperature and water stress at two species of wheat were investigated, the highest SOD activities were identified when temperature and water stress affect together (Keleş and Öncel, 2000). In the study in which the plants adapted to high mountains and steppe conditions were compared in regard to their SOD activities; while the average of SOD activity was determined as 213 units in high mountain plants, it was determined as 134 units in steppe plants (Öncel et al., 2004). While SOD activity was identified as high at the species of Poaceae invested in the same study, it was identified as quite changeable at the species of Lamiaceae. The SOD activity was identified as 225 units at the species

\section{References}

Ajaib M, Khan KM, Perveen S, Shah S. (2013). Antimicrobial and antioxidant activities of Echinochloa colona (Linn.) link and Sporobolus coromandelianus (Retz.) Kunth. J. Chem. Soc. Pakistan 35: 960- 965.

Albayrak S, Aksoy A, Hamzaoğlu E (2008). Determination of antimicrobial and antioxidant activities of Turkish endemic Salvia halophila Hedge. Turk J. Biol 32: 265-270.

Alscher RG, Hess JL (1993). Antioxidants in higher plants. Boca Raton: CRC Pres, pp 1-20.

Başer KHC (1993). Essential oils of Anatolian Labiateae: A profile. Acta Horticulturae 333: 217-237.

Beyer WF, Fridovich I (1987). Assaying for superoxide dismutase activity some large consequences of minör changes in conditions. Anal. Biochem 161: 559-566.

Bowler C, van Montagu M, Inze D (1992). Superoxide dismutase and stress tolerance. Annu. Rev. Plant Physiol. Plant Mol. Biol 43: 83-116

Cai Y, Luo Q, Sun M, Corke H (2004). Antioxidant activity and phenolic compounds of 112 traditional Chinese medicinal plants associated with anticancer. Life Sci 74: 2157-2184.

Castrillo M, Vizcaino D, Moreno E, Latorraca Z (2001). Chlorophyll content in some cultivated and wild species of the family Lamiaceae" Biologia Plantarum 44: 423-425.

De Marino S, Festa C, Zollo F, Incollingo F, Raimo G, Evangelista G, Iorizzi M (2012). Antioxidant activity of phenolic and phenylethanoid glycosides from Teucrium polium L. Food Chem 133: 21-28.

Ebrahimzadeh MA, Pormorad F, Hafezi S (2008). Antioxidatif activities of Iranian corn silk. Turk J. Biol 32: 43-49.

El-Qudah JM (2014). Contents of Chlorophyll and Carotenoid pigments in common Thyme (Thymus vulgaris L.). World App. Sci. J 29: 1277-1281.

Erdemoğlu N, Turan NN, Çakıcı I, Şener B, Aydın A (2006). Antioxidant activities of some Lamiaceae plant extracts. Phytotherapy Res 20: 9-13.

Erdoğan I, Baki E, Senol S, Yılmaz G (2010). Sage-called plant spieces sold in Turkey and their antioksidant activities. J. Serb. Chem. Soc 75: 1491-1501.

Ferraris L, Abbatista-Gentile I, Matta A (1987). Variations of phenols concentrations as a concequence of stressses that induce resistence to Fusarium wild of tomato. J. Plant Dis. Protec 94: 624-629.

Güner A, Özhatay N, Ekim T, Başer KHC (2000). Flora of Turkey and the East Aegean Islands (supplement 2), Edinburgh University Pres, Edinburgh.

Kahraman A, Celep F, Doğan M (2009). Morphology, anatomy and palynology of Salvia indica L. (Labiatae). World Appl. Sci. J 6: $289-296$

Keles Y, Öncel I. (2000). Changes of superoxide dismutase activity in wheat seedlings exposed to naturel environmetal stresses. Commun. Fac. Sci. Univ. Ank. Series C 18: 1-8.

Keleş Y, Everest A (2008). Relation to altitude adaptation and antioxidant defence system in five shrubs and trees species from Middle Taurus mountains. Int. J. Natural Engineer. Sci. 2: 45-49.

Knezevic SV, Blazekoviç B, Stefan BM, Alegro A, Köszegi T, Petrik J (2011). Antioksidant activities and polyphenolic contents of three selected Micromeria species from Croatia. Molecules 16: 1454-1470.

Lu Y, Foo Y (2002). Polyphenolics of Salvia a reviewe. Phytochemistry 59: 117-140.

Markovskaya E, Schmakova N, Sergienko L (2012). Ecophysiological characteristic of the costal plants in the conditions of the tidal zone on the costs of Svalbard. Czech Polar Reports 2: 103-108. 
Matkowski A, Zieliska S, Oszmianski J, Zarawska EL (2008). Antioksidant activity of extracts from leaves and roots of Salvia mitiorrhiza Bunge, Salvia przewalskii Maxim, Salvia verticillata L. Bioresource Technol 99: 7892-7896.

Mitler R (2002). Oxidative stress, antioxidants and stress tolerance. Trends Plant Sci 7: 405-410.

Moore TC (1974). Research Experiences in Plant Physiology. Springer, New York.

Öncel I, Yurdakulol E, Keleş Y, Kurt L, Yıldız A (2004). Role of antioxidant defense system and biochemical adaptation on stres tolerance of high mountain and stepe plants. Acta Oecol 26: 211-218.

Porra RJ, Thompson RA, Kriedemann PE (1989). Determination of accurate extinction coefficients and simulations equations for assaying chloropylls a and $\mathrm{b}$ extracted with four different solvent verification of the concentration of chlorophyll standards by atomic absorption spectroscopy. Biochem. Biophys. Acta 975: 384-394.

Prieto P, Pineda M, Aguilar M (1999). Spectrophotometric Quantitation of antioxidant capacity through the formation of a phosphomolybdenum complex: Specific application to the Determination of vitamin E. Anal. Biochem 269: 337-341.

Reddy SS, Krishnan C (2013). Characterization of enzyme released antioxidant phenolic acids and xylooligosaccharides from different Graminae or Poaceae members. Food Biothec 27: 357-370.

Rice-Evans AC, Miller NJ, Papanga G (1996). Structure-antioxidant activity relationship of flavonoids and phenolic acids. Free Radical Biol. Med 20: 933-956.

Schoner S, Krause GH (1990). Protective systems against active oxygen species in spinach - response to cold-acclimation in excess light. Planta 180: 383-389.

Swedan EA (2013). PAL gene activity and total phenolic compounds in some members of Lamiaceae. J. Appl. Sci. Res 9: 12221227.

Triantaphyllou K, Blekas G, Boskou D (2001). Antioxidatif properties water extrcts obtained from herbs of the species Lamiaceae. Int. J. Food Sci. Nutrition. 52: 313-317.

Udin MdK, Juraimi AS, Ismail MR, Hossain MdA, Othman R, Rahim AA (2012). Physiological and growth responses of six turfgrass species relative to salinity tolerance. Scientific World J 2012: 1-10.

Wojdylo A, Oszmianski J, Czemerys R (2007). Antioxidant activity and phenolic compounds in 32 selected herbs. Food Chem 105: 940-949.

Van Breusegem F, Dat JF (2006). Reactive oxygen species in plant cell death. Plant Physiol 141: 384-390.

Cite this article: Sağır C, Everest ZA, Keleş Y (2018). The comparative investigation of the antioxidant activities of some species belonging to the Lamiaceae ve Poaceae families. Anatolian Journal of Botany 2(2): 52-59. 